\title{
ロシンポジウム II：進行性失語
}

\section{失語像の多様性：“logopenic”型原発性進行性失語を中心に}

\author{
吉 野 眞理子*
}

\begin{abstract}
要旨：原発性進行性失語（以下, PPA）の失語像の多様性について, “logopenic”型 PPAを中心に分類上 の問題点を考察した。英語圈症例の示す臨床症状の検討をもとに確立されたPPAの分類基準を用いて, 日本語話者 PPA 文献例の分類を試みた。その結果, 全 87 例のうち, 非流暢・失文法型に 12 例, 意味型 に 7 例, “logopenic” 型に 13 例が分類され, 残り 55 例はどの亜型にも分類できなかった。その要因として, 言語症状の記載の欠如, 検查時期の問題, 3 亜型分類の解剖学的・病理学的基盤の問題が挙げられた。日 本語話者における PPA症候学の確立のために, 少なくとも前 2 者の問題を解決する必要があると思われる。
\end{abstract}

(高次脳機能研究 33 (3) : $324 ＼mathrm{~ 329 ， 2013) ~}$

Key Words : 原発性進行性失語, 診断基準, 非流暢 ·失文法型, 意味型, “logopenic”型 primary progressive aphasia, diagnostic criteria, agrammatic/nonfluent variant, semantic variant, logopenic variant

\section{はじめに}

“logopenic” 型 PPA（logopenic variant of primary progressive aphasia : lvPPA) は, Gorno-Tempini ら

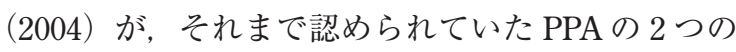
サブタイプである進行性非流暢性失語（progressive nonfluent aphasia:PNFA) と意味性認知症（semantic dementia：SD）に加わる第 3 の亜型として新たに 提唱した臨床症候群である。中核症状は, 自発話お よび呼称における喚語障害と文・句の復唱障害であ る。自発話は, 喚語困難のためしばしばポーズがあ るが明らかな失文法はない。遅くたどたどしい発話 で発話運動面の誤りや失文法が著明な PNFA とは 異なる。呼称障害は SD ほど重症でないのがふつう であり，誤りは音韻論的な誤りである。

2006 ～ 2009 年に英語圈の著名な研究者たちが集 い, PPA 症例のビデオを検討して PPA 亜型の共通 した分類システムを確立するための議論を行った。 その成果として 2011 年に, 「非流暢 / 失文法型」,「意 味型」,「“logopenic” 型」の 3 型の PPA に対応する 診断基準が提唱された（Gorno-Tempini ら 2011）。 “logopenic” 型 PPAの臨床的診断基準として, 2つ の中核症状と 4 つの周辺症状が示されている。これ らは, PPAの比較的初期段階に適用可能とされて いる。

その後さらに報告が積み重ねられ, 定量的分類の
試みもなされているが，問題も浮かび上がってきて いる。かなりの割合の PPA 患者が意味型でも非流 暢型でもないものの必ずしも “logopenic” 型に一致 しないという報告（Sajjadi ら 2012）や，病初期・ 軽症期の検討から第 4 の型「混合型」を示唆する報 告（Mesulam ら 2012）などである。これらは英語 圈の研究であるが, 日本語において報告されている PPA 症例ではどうであろうか。筆者は “logopenia” (発話がそしいという意味) を呈さない “logopenic” 型 PPA を経験している（吉野 2011）。本稿では，日 本語話者における文献例と自験例をもとに失語の臨 床像の多様性と分類上の問題点について検討する。

\section{I . 原発性進行性失語（PPA）と その亜型の分類基準}

英語圈において公認されている Gorno-Tempini ら（2011）の診断基準の概略を示す。まずPPAの 診断基準は, 表 1 のとおりである。この診断基準 をみたす PPA はさらに 3 亜型に分けられるが, そ れらの臨床診断基準を表 2 に示す。 3 西型の診断基 準にはさらに，画像に裏づけられた診断基準，確定 病理学的診断基準が示されているが, 本稿ではこれ らは割愛する。表 2 の臨床診断基準を小森（2012） を参考に整理して 3 型を対比して示したものが表 3 である。 
表 1 原発性進行性失語（PPA）の診断基準：Mesulam（2001，2003）に基づく

・包含基準 : 1 〜 の基準を満たさなければならない。

1.もつとも顕著な臨床症状は言語の困難である。

2.これらの障害が日常生活における障害の主たる要因である。

3. 発症時执よび病初期において失語がもつとも目立つ障害である。

・除外基準：PPAの診断のためには 1 ～９基準が否定されなければならない。

1. 他の非変性性神経系障害または医学的疾患により障害パターンがよりよく説明される。

2. 精神科的診断により認知障害がよりよく説明される。

3. 顕著な初期のエピソード記憶, 視覚性記憶, 視知覚性の障害

4. 顕著な初期の行動障害

Abbreviation : PPA $=$ primary progressive aphasia

表 2 PPA サブタイプの臨床診断基準（1）

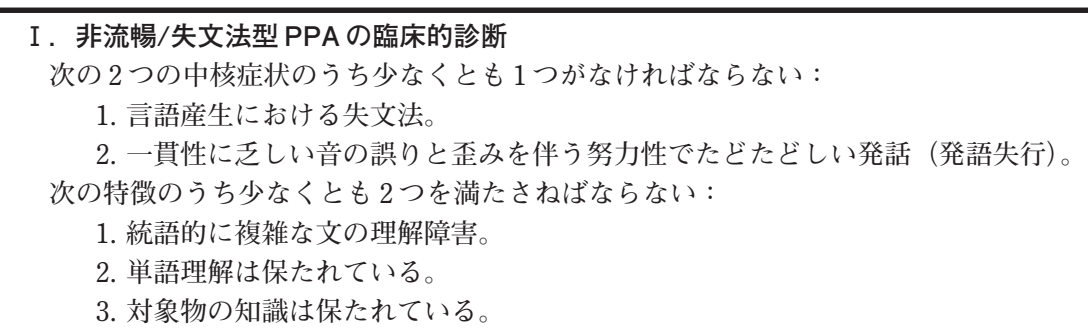

\section{II. 意味型PPAの臨床的診断}

次の 2 つの中核症状がなければならない：

1. 呼称障害。

2. 単語の理解障害。

次の特徴のうち少なくとも 3 つを満たさねばならない：

1. 対象物の知識の障害，とくに低頻度または低親密度項目について。

2. 表層性失読。

3. 復唱は保たれている。

4. 発話産生（文法, 発話運動面）は保たれている。

\section{III. “logopenic”型PPA の臨床的診断}

次の $2 つ$ つ核症状がなければならない：

1. 自発話および呼称における単語回収障害。

2. 文・句の復唱障害。

次の特徴のうち少なくとも 3 つを満たさねばならない：

1. 自発話および呼称における発話の音韻論的誤り。

2. 単語理解と対象物の知識は保たれている。

3. 発話運動面は保たれている。

4. 明らかな失文法はない。

\section{II. “logopenic”型 PPA 自験例}

シンポジウムでは, “logopenic”型 PPA 自験例の 臨床像の経過を提示したが, 本稿では紙幅の都合で 省略させていただく。詳細は, 吉野（2011）を参照 されたい。

\section{III. 日本語話者 PPA 文献例の検討}

Gorno-Tempini ら（2011）の診断基準は，英語 話者における臨床症状を検討して得られたものであ るが，それが日本語話者における PPAの分類にも 有効であるかについては検討を要すると思われる。 そこで, 日本語話者 PPA と思われる文献例を, 医 
表 3 PPA サブタイプの臨床診断基準（2）

\begin{tabular}{|c|c|c|c|}
\hline & 非流暢 - 失文法型 & 意味型 & “logopenic" 型 \\
\hline \multirow[t]{2}{*}{ 中核症状 } & 発話における失文法 & 呼称障害 & $\begin{array}{l}\text { 自発話・呼称における } \\
\text { 喚語障害 }\end{array}$ \\
\hline & 発語失行 & 単語の理解障害 & 文·句の復唱障害 \\
\hline \multirow[t]{4}{*}{ 支持項目 } & $\begin{array}{l}\text { 統語的に複雑な文の } \\
\text { 理解障害 }\end{array}$ & $\begin{array}{l}\text { 対象物知識の障害 } \\
\text { (低頻度 · 親密度) }\end{array}$ & 音韻性錯語 \\
\hline & 単語理解の保存 & 表層性失読 & $\begin{array}{l}\text { 単語理解·対象物知識 } \\
\text { の保存 }\end{array}$ \\
\hline & 対象物知識の保存 & 復唱能力の保存 & 発話運動面の保存 \\
\hline & & $\begin{array}{l}\text { 発話産生（文法, 発話 } \\
\text { 運動面）の保存 }\end{array}$ & 明らかな失文法なし \\
\hline \multirow[t]{2}{*}{ 診断基準 } & 中核症状 $\geq 1 / 2$ & 中核症状 $\geq 2 / 2$ & 中核症状 $\geq 2 / 2$ \\
\hline & 支持項目 $\geq 2 / 3$ & 支持項目 $\geq 3 / 4$ & 支持項目 $\geq 3 / 4$ \\
\hline
\end{tabular}

(小森（2012）を参考に整理)

中誌による検索，前田（1999），小川ら（2011）な どの総説を参考に収集した(会議録は除いた)。個々 の文献記載を検討し, 複数の文献で重複して報告さ れている例を 1 つにまとめ, 記憶障害や行動障害が 先行するなど PPAの診断基準に合わないものは除 外した。さらに記載された症状が比較的初期段階の ものではなく，かなり進行してからのもののみであ る場合も除外した。これはこの診断基準の適用外と されているためである。その結果, 収集し得た範囲 で 87 例の報告があった。

記載された言語症状を検討し, Gorno-Tempini ら（2011）の診断基準を基に分類を試みた。まず非 流暢・失文法型である。すなわち，中核症状である 「発話における失文法」と「発語失行」のどちらか があり,「統語的に複雑な文の理解障害」,「単語理 解の保存」,「対象物の知識の保存」の 3 項目中 2 項 目以上をみたすことが求められている。しかしなが ら「統語的に複雑な文の理解障害」に言及している 文献はわずかであったので，文レベルの理解障害が ある程度認められるものもこれに準ずるものとし た。また,「対象物の知識の保存」を検討している 文献も僅かであったので，語義理解障害がないもの もこれに準ずるものとした。その結果，非流暢・失 文法型 PPA に分類された症例は，表 4 に示す 12 例 であった。

次に，意味型である。すなわち，中核症状である 「呼称障害」と「単語の理解障害」の両者があり,「対 象物の知識の障害」,「表層性失読」,「復唱の保存」, 「文法, 発話運動面の保存」の 4 項目中 3 項目以上
をみたすことが求められている。ここでもまた,「対 象物の知識の障害」,「表層性失読」については検討 していない文献が多かったことも与って，意味型 PPAに分類し得たのはわずかに7例であった(表 5)。

最後に “logopenic” 型PPA である。中核症状で ある「自発話および呼称における単語回収障害」と 「文・句の復唱障害」の両者があり，「音韻性錯語あ り, 「単語理解と対象物の知識の保存」, 「発話運動 面の保存」,「明らかな失文法なし」の 4 項目中 3 項 目以上をみたすことが求められている。ここでは失 文法に言及している文献がそしかったものの 13 例 が “logopenic”型に分類された（表 6）。

3 亜型の間で重複して分類された症例はなく, 残 る 55 例は分類できなかった。

\section{IV. 分類困難の要因}

分類を困難にした要因について考察する。

まず，言語症状について必要な情報が記載されて いないことが挙げられる。とくに,「発語失行や構 音の障害」,「対象物知識の障害」,「発話における失 文法」,「統語的に複雑な文の理解」について記載の ないものが多くみられた。検査プロフィールがない ために，理解障害や復唱障害が単語レベルか文レベ ルか判別できないことも多く，結果として「単語の 理解障害」，「文の復唱障害」といった当たり前の症 状についても有無が読み取れないものが多かった。 プロフィールがあっても WAB では，単語レベルと 文レベルの区別がわかりがたい。また，たとえば復 唱成績の低下が，構音の問題のためか，音韻性錯語 
表 4 非流暢・失文法型PPA に分類された症例

\begin{tabular}{|c|c|c|c|c|c|c|c|c|c|c|c|c|}
\hline 著者名 & 年 & case no. & $\begin{array}{l}\text { 発症時 } \\
\text { 年齢 }\end{array}$ & 性 & 利き手 & $\begin{array}{c}\text { 構音/ } \\
\mathrm{AOS}\end{array}$ & $\begin{array}{c}\text { 文の理解 } \\
\text { 障害 }\end{array}$ & $\begin{array}{c}\text { 単語理解 } \\
\text { 障害 }\end{array}$ & $\begin{array}{c}\text { 語義理解 } \\
\text { 障害 }\end{array}$ & $\begin{array}{l}\text { 対象物知 } \\
\text { 識の障害 }\end{array}$ & $\begin{array}{c}\text { 失文法 } \\
\text { (発話) }\end{array}$ & $\begin{array}{l}\text { 失文法 } \\
\text { (理解) }\end{array}$ \\
\hline 福迫陽子，ほか & 1991 & 1 & 72 & $\mathrm{M}$ & $\mathrm{R}$ & ++ & - & - & - & $?$ & $?$ & $?$ \\
\hline Fukui, T., et al. & 1996 & & 62 & $\mathrm{M}$ & $\mathrm{R}$ & +++ & - & - & - & $?$ & $?$ & $?$ \\
\hline 清水隆史, ほか & 1997 & & 45 & $\mathrm{~F}$ & $\mathrm{R}$ & $++?$ & ++ & \pm & - & $?$ & $?$ & $?$ \\
\hline 奥田＼cjkstart聡 & 1999 & & 62 & $\mathrm{~F}$ & $\mathrm{R}$ & $?$ & + & \pm & - & $?$ & ++ & $?$ \\
\hline 松田正之，ほか & 2000 & & 65 & M & $\mathrm{R}$ & ++ & + & \pm & - & $?$ & ++ & $?$ \\
\hline 国吉和昌，ほか & 2002 & 1 & 68 & $\mathrm{~F}$ & $?$ & $?$ & ++ & \pm & $?$ & $?$ & ++ & $?$ \\
\hline 南 夏美, ほか & 2002 & & 64 & $\mathrm{~F}$ & $\mathrm{R}(\mathrm{L})$ & ++ & - & - & - & $?$ & $+?$ & $?$ \\
\hline 瓦林 毅, ほか & 2005 & & 63 & $\mathrm{~F}$ & $?$ & ++ & + & \pm & - & $?$ & ++ & + \\
\hline Takao, M., et al. & 2006 & & 60 & M & $\mathrm{R}$ & ++ & + & \pm & $?$ & $?$ & $?$ & $?$ \\
\hline 鈴木圭輔，ほか & 2011 & & 59 & $\mathrm{~F}$ & $?$ & ++ & ++ & + & - & $?$ & $?$ & $?$ \\
\hline 河村 満, ほか & 2012 & 1 & 61 & $\mathrm{~F}$ & $\mathrm{R}$ & ++ & - & - & - & $?$ & $?$ & $?$ \\
\hline 小森憲治郎 & 2012 & 1 & 67 & $\mathrm{~F}$ & $\mathrm{R}$ & ++ & + & \pm & - & $?$ & ++ & $?$ \\
\hline
\end{tabular}

一 : 症状なし, \pm : 症状ほとんどなし + ：症状あり, ++ : 症状かなりあり, +++ 症状著しくあり，?:不明 $\operatorname{AOS}:$ 発語失行

表 5 意味型PPAに分類された症例

\begin{tabular}{|c|c|c|c|c|c|c|c|c|c|c|c|c|}
\hline 著者名 & 年 & case no. & $\begin{array}{l}\text { 発症時 } \\
\text { 年齢 }\end{array}$ & 性 & 利き手 & $\begin{array}{l}\text { 構音/ } \\
\text { AOS }\end{array}$ & $\begin{array}{c}\text { 単語理解 } \\
\text { 障害 }\end{array}$ & $\begin{array}{c}\text { 語義理解 } \\
\text { 障害 }\end{array}$ & $\begin{array}{l}\text { 対象物知 } \\
\text { 識の障害 }\end{array}$ & $\begin{array}{l}\text { 喚語 } \\
\text { 障害 }\end{array}$ & $\begin{array}{c}\text { 復唱 STM } \\
\text { 障害 }\end{array}$ & $\begin{array}{l}\text { 表層 } \\
\text { 失読 }\end{array}$ \\
\hline 地引逸亀, ほか & 1979 & & 56 & $\mathrm{~F}$ & $\mathrm{R}$ & - & +++ & +++ & ? & +++ & - & + ? \\
\hline 松原三郎，ほか & 1984 & & 47 & M & $\mathrm{R}$ & - & + & ++ & $?$ & ++ & - & ++ \\
\hline 岡田真一, ほか & 2000 & & 70 & $\mathrm{~F}$ & $\mathrm{R}$ & - & ++ & + & + & ++ & + & + \\
\hline Fushimi, T., et al. & 2003 & & 54 & M & $\mathrm{R}$ & - & \pm & ++ & $?$ & ++ & - & ++ \\
\hline 吉野文浩，ほか & 2012 & 1 & 65 & $\mathrm{~F}$ & $\mathrm{R}$ & - & ++ & ++ & ++ & ++ & - & + \\
\hline 一美奈緒子, ほか & 2012 & 1 & 53 & $\mathrm{~F}$ & $\mathrm{R}$ & - & ++ & ++ & $?$ & ++ & - & $?$ \\
\hline 一美奈緒子, ほか & 2012 & 2 & 62 & $\mathrm{~F}$ & $\mathrm{R}$ & - & + & ++ & $?$ & ++ & - & $?$ \\
\hline
\end{tabular}

一：症状なし，士：症状ほとんどなし， + : 症状あり，+十:症状かなりあり，+十+：症状著しくあり，?：不明 AOS : 発語失行

表 6 “logopenic”型PPA に分類された症例

\begin{tabular}{|c|c|c|c|c|c|c|c|c|c|c|c|c|c|c|}
\hline \multirow{2}{*}{ 著者名 } & \multirow{2}{*}{ 年 } & \multirow{2}{*}{ case no. } & \multirow{2}{*}{$\begin{array}{l}\text { 発症時 } \\
\text { 年齢 }\end{array}$} & \multirow{2}{*}{ 性 } & \multirow{2}{*}{ 利き手 } & \multirow{2}{*}{$\begin{array}{l}\text { 構音/ } \\
\text { AOS }\end{array}$} & \multirow{2}{*}{$\begin{array}{c}\text { 単語理解 } \\
\text { 障害 }\end{array}$} & \multirow{2}{*}{$\begin{array}{c}\text { 語義理 } \\
\text { 障害 }\end{array}$} & \multirow{2}{*}{$\begin{array}{c}\text { 多対象物知 } \\
\text { 識の障害 }\end{array}$} & \multirow{2}{*}{$\begin{array}{l}\text { 喚語 } \\
\text { 障害 }\end{array}$} & \multirow{2}{*}{$\begin{array}{l}\text { 統語障害 } \\
\text { ·失文法 } \\
\end{array}$} & \multirow{2}{*}{$\begin{array}{l}\text { 失文法 } \\
\text { (発話) }\end{array}$} & \multicolumn{2}{|c|}{ 音韻障害 文の復唱 } \\
\hline & & & & & & & & & & & & & /錯語 & 障害 \\
\hline 山本 徹, ほか & 1989 & 1 & 49 & $\mathrm{M}$ & $\mathrm{R}$ & - & $?$ & - & $?$ & +++ & $?$ & $?$ & + & + \\
\hline 金子真人, ほか & 1995 & & 63 & $\mathrm{~F}$ & $\mathrm{R}$ & - & \pm & - & $?$ & +++ & ++ & + & + & +++ \\
\hline Hachisuka, K., et al. & 1999 & & 60 & $\mathrm{~F}$ & $\mathrm{R}$ & - & $?$ & - & $?$ & + & + & $?$ & ++ & +++ \\
\hline 軸丸美香，ほか & 2000 & & 66 & $\mathrm{~F}$ & $\mathrm{R}$ & - & \pm & - & $?$ & + & $?$ & $?$ & ++ & +++ \\
\hline 関口恵利, ほか & 2006 & & 69 & M & $\mathrm{R}$ & - & \pm & - & $?$ & + & $?$ & $?$ & ++ & +++ \\
\hline 石丸美和子, ほか & 2007 & & 59 & $\mathrm{~F}$ & $\mathrm{R}$ & - & \pm & - & $?$ & + & $?$ & $?$ & + & ++ \\
\hline 水野真由子，ほか & 2008 & & 72 & $\mathrm{~F}$ & $\mathrm{R}$ & - & - & - & $?$ & + & $?$ & $?$ & ++ & + \\
\hline 小森憲治郎 & 2009 & 2 & 56 & M & $\mathrm{R}$ & - & $?$ & - & $?$ & + & $?$ & $?$ & ++ & +++ \\
\hline 小川七世, ほか & 2010 & & 52 & M & $\mathrm{R}$ & - & $?$ & - & $?$ & + & $?$ & $?$ & ++ & +++ \\
\hline 坂根理絵子，ほか & 2011 & & 66 & $\mathrm{~F}$ & $\mathrm{R}$ & - & \pm & - & $?$ & + & $?$ & $?$ & ++ & ++ \\
\hline 吉野眞理子 & 2011 & & 60 & M & $\mathrm{R}$ & - & \pm & - & - & + & + & - & ++ & +++ \\
\hline 小森憲治郎 & 2012 & 3 & 61 & $\mathrm{M}$ & $\mathrm{R}$ & - & + & - & $?$ & + & $?$ & $?$ & + & ++ \\
\hline 吉野文浩, ほか & 2012 & 2 & 57 & $\mathrm{~F}$ & $\mathrm{R}$ & - & + & - & - & ++ & $?$ & $?$ & ++ & ++ \\
\hline
\end{tabular}

一 : 症状なし, \pm : 症状ほとんどなし, + : 症状あり, ++ : 症状かなりあり, +++ : 症状著しくあり, ? : 不明 AOS : 発語失行 
のためか, 言語性短期記憶障害のためか, 注意障害 のためか, 不明のものも多い。

次に, 検査時期の問題が挙げられる。進行が進み PPA といえない状態になってから初めて検査を施 行されている場合が少なからずあり，病像の特徵把 握を難しくする要因となっている。

さらに, 非流暢・失文法型 PPA と “logopenic” 型 PPAには, 中心病巣の上で重なりがあるので, 臨床症状から分類しょうとしたとき，どちらかに分 類できない場合が生じても不思議はない。英語圈で 報告されているような第 4 の亜型やさらなるサブ夕 イプがある可能性も否定できない。

最後に根本的な問題として, 各亜型と病理との対 応は複雑であり（Harciarekら 2011），これら亜型 分類が病理的基盤に支えられているとは限らないこ とが問題を複雑にしている。

\section{PPA 症候学の確立のために}

日本語話者におけるPPAの症候学を確立するた めには,まず言語症状を詳細に記載する必要がある。 とくに, 発話運動面, 理解・表出における失文法, 単語レベル・文レベルの理解および復唱障害, 日本 語に特異的な読久書き障害（類音性錯読・錯書）な どについて，客観的検査成績とともに示すことが求 められる。英語圈においてなされたような臨床症状 の検討には，ビデオや音声のデー夕もあると有用で あろう。PPAが進行すると失語が重症化し, 特徵 的な症状を把握しにくくなるので, 他の認知機能障 害があまり見られない初期段階に失語を評価するこ とも必要である。できれば同時期に脳の機能画像が
得られ，最終的に病理学的診断もなされれば, これ らとの関連も検討できるであろう。臨床症状の経過 についてもできるだけ追うことができると, 症候学 の確立に貢献できるであろう。

\section{文献}

1 ) Gorno-Tempini, M. L., Dronkers, N. F., Rankin, K. P., et al. : Cognition and anatomy in three variants of primary progressive aphasia. Ann. Neurol., 55 (3) : 335-346, 2004.

2 ) Gorno-Tempini, M. L., Hillis, A. E., Weintraub, S., et al. : Classification of primary progressive aphasia and its variants. Neurology, $76: 1006-1014,2011$.

3 ) Harciarek, M. \& Kertesz, A. : Primary progressive aphasias and their contribution to the contemporary knowledge about the brain-language relationship. Neuropsychol. Rev., 21 (3) : 271-287, 2011.

4 ）小森憲治郎：原発性進行性失語：その症候と課題。高次 脳機能研究, 32 (3) : 393-404, 2012.

5 ）前田真治：【緩徐進行性失語症】本邦報告例の統計。神 経内科, $51: 225-238,1999$.

6 ) Mesulam, M. M., Wieneke, C., Thompson, C., et al. : Quantitative classification of primary progressive aphasia at early and mild impairment stages. Brain, 135 : 1537-1553, 2012.

7 ）小川七世, 西尾慶之： logopenic progressive aphasia：第 3 の原発性進行性失語. 神経心理学, 26:294-303, 2011.

8 ) Sajjadi, S. A., Patterson, K., Arnold, R. J., et al. : Primary progressive aphasia : a tale of two syndromes and the rest. Neurology, $78:$ 1670-1677, 2012.

9 ) 吉野眞理子：“Logopenic”型原発性進行性失語. BRAIN \& NERVE, 63 (10) : 1057-1067, 2011. 


\section{Abstract}

\section{Diversified clinical features of primary progressive aphasias : an investigation of reported Japanese cases including logopenic variant of primary progressive aphasia}

\section{Mariko Yoshino*}

Primary progressive aphasia (PPA) has been proposed to comprise 3 clinical subtypes : agrammatic/ nonfluent, semantic, and logopenic variants. With the aim to evaluate this tripartite system developed by investigating English speaking PPA cases, reported Japanese cases presenting as PPA were classified into one of the three variants using this clinical classification system. Of the 87 reported cases met cliteria of PPA, 12 cases, 7 cases, and 13 cases fitted agrammatic/nonfluent, semantic, and logopenic categories respectively, and 55 cases did not fulfill the diagnostic criteria for any of the 3 variants. For the most part, the inability to classify might be caused by lack of clinical features recorded, testing time after onset, and overlapping anatomical and pathological substrates of the 3 variants. 